\title{
Effective Participation and Motivation: An Investigation on Secondary School Students
}

\author{
Adnan Tasgin ${ }^{1, *} \&$ Yunus Tunc ${ }^{2}$ \\ ${ }^{1}$ Faculty of Education, Atatürk University, Erzurum, Turkey \\ ${ }^{2}$ Vocational School of Health Services, Igdır University, Igdır, Turkey \\ *Correspondence: Faculty of Education, Atatürk University, Yakutiye-Erzurum, Turkey. E-mail: \\ atasgin@atauni.edu.tr
}

Received: January 24, 2018

Accepted: February 18, 2018 Online Published: February 20, 2018

doi:10.5430/wje.v8n1p58

URL: https://doi.org/10.5430/wje.v8n1p58

\begin{abstract}
The aim of this study is to examine the relationship between the secondary school students' level of effective participation and their motivation. This study employs a survey consisting of 251 secondary school students from the schools located in Iğdır and Erzurum, in East of Turkey. The data of the study were gathered through "Effective Participation Scale" and "Intrinsic-Extrinsic Motivation Scale". The analysis of the obtained data showed that female secondary school students are academically more engaged than the male students and male secondary school students are more disaffected than the female students. It has been found that students engage in English and Turkish lessons more than Mathematics and they are disaffected with Mathematics at most. It has been determined that academically engaged students' intrinsic motivations increase in the positive direction while that of the disaffected students' decrease as the class levels increase.
\end{abstract}

Keywords: effective participation, motivation, engagement, disaffection, secondary school students

\section{Introduction}

In their study, (Aypay \& Eryllmaz, 2011) describe motivation as the energy of individual's behaviour, while they define participation as the link between the individual and the activity. Effective participation in the school environment represents the degree of active involvement of a student in classroom learning activities. On the other hand, motivation in the school environment is a process for the students to initiate and execute the class activity. The motivating processes that strengthen and sustain the classroom activities of the students are multi-dimensional and include the needs, expectations or beliefs and goals of the students (Lee \& Reeve, 2012).

Students who have been motivated to learn, that is all the needs and expectations are met, show the following behaviours: participate in class, repeat knowledge, relate to their existing knowledge and ask questions. In short, these students are eager to learn. A student's reactions towards learning lead him to success. It is not possible to talk about success for individuals who are not in action (Schunk, 2009).

Teachers' supportive role in the classroom is another important aspect in ensuring the students' effective participation. The teachers try to motivate the students in the best way. Sometimes there are introvert students or students who does not actively participate in the classroom. The teacher should reinforce and appreciate the positive behaviour of such students. They should give opportunities to such students and plan activities according to their interests and needs. A strong teacher-student relationship has a positive effect on students' active participation and motivation.

If the students are motivated for learning, they participate actively in activities. High motivation and engagement are necessary for the success of learning process. In the light of this information, it is understood that motivation and effective participation are inseparable concepts and they have an important role in learning.

\subsection{Effective Participation}

One of the most important components affecting the quality of the teaching process is effective participation. Motivation has a separate place and importance among the factors of effective participation. The higher the 
motivation of the students for the learning process, the higher the level of effective participation in the lessons. The literature has various explanations about effective participation and motivation.

Effective participation can be defined as an individual's highest engagement to an academic activity (Güneri, 2013) and students' active involvement in the learning process (Christenson, Reschly \& Wylie, 2012). Turkish Language Society's Great Turkish Dictionary defines it as "taking part in a process or situation by willingly or being active in an event" (TDK, 2011), participation is defined as loyalty, attractiveness and relevance in New American dictionary (Sarttepeci, 2012). The best indicator of the quality of instructional activities is the level of participation of students in the learning-teaching process. If nearly all of the students participate in the learning-teaching process, this indicates that the quality of the teaching methods used is sufficient (Sarıtepeci \& Çakır, 2015). Besides, the student' level of readiness and environmental conditions also affect the student' effective participation in teaching environment (Can, 2005). If the students effectively involve the learning process, they will have more permanent learning experiences (Demirel, 2009). Moreover, students' participation in the learning process also contributes to their academic competence, achievement, socialization and life satisfaction (Harris, 2008; Lewis, 2010; Wang \& Eccles, 2012).

Another important issue of effective participation is the extent to which teachers motivate their students to involve in enriching the teaching process. In ensuring effective participation of students, teachers should be able to use extrinsic stimuli as well as create opportunities for students to use their internal stimuli. For example, while teachers can use reward and reinforcement tariffs as external stimuli, students may participate in the process by themselves if the teachers prepare the necessary environment and materials in an interesting and attractive way.

Techniques such as group work, drama, and analogy should be used to ensure student engagement. Teachers should use different teaching strategies, methods and techniques to ensure that students are actively involved in the learning process. In order to accomplish this, it is necessary for the teachers to have a rich method knowledge (Demirel, 2009).

The researchers agree that there are three dimensions to student participation, namely behavioural engagement, emotional engagement and cognitive engagement (Skinner, Kindermann \& Furrer 2009; Towler, 2010; Wang, Bergin \& Bergin, 2014). They can be explained as below:

a) Behavioural engagement: Students who are behaviourally engaged would typically comply with behavioural norms, such as attendance and involvement, and would demonstrate the absence of disruptive or negative behaviour.

b) Emotional engagement: Students who engage emotionally would experience affective reactions such as interest, enjoyment, or a sense of belonging.

c) Cognitive engagement: Cognitively engaged students would be invested in their learning, would seek to go beyond the requirements, and would relish challenge.

Coates (2007) has described engagement as (a) active and collaborative learning, (b) participation in challenging academic activities, (c) formal communication with academic staff, (d) involvement in enriching educational experiences, and (e) being supported and legitimated by university learning communities.

Briefly, an individual's participation will be at a higher level if the teaching-learning process meets and suits his needs, drives him to achievement and provides meaningful products to him. If external conditions provided in teaching-learning environment correspond to the student's internal conditions, then participation will be at the highest level (Aykaç, 2014).

Research has shown that the students who have high self-esteem participate more and have better academic performance (Pajares, 1996; Schunk, 1995). Moreover, student participation is also affected by the teachers' characters and skills. If the teachers have the ability to use supportive, gentle, friendly and warm-hearted gestures and mimics, the students can be more active in the process (Dallimore, Hertenstein \& Platt, 2004; Fassinger, 2000).

It has been the subject of many researches that the students' disengagement in the lectures will not only lead them not to fulfill their development tasks but also will cause some social problems. Some research has shown that if the students do not have motivation for participation, they become bored and cannot focus. As a result of these negativities, the students were bored half of the time they had spent at school, they became academically unsuccessful and finally they left the school. It has been emphasized that families, teachers and school administrators must have sufficient knowledge and skills that provide students' effective participation (Eryllmaz, 2013).

When the literature on effective participation is reviewed, it is seen that there is a meaningful relationship between 
the high school students' motivation and their participation (Güvenç, 2011). There are also studies that show if the high school students have positive attitude towards lectures, they have high motivation for effective participation (Eryılmaz, Yıldız \& Akın, 2011). Moreover, it has been found that female students' participation is higher when compared to male students (Güvenç \& Koç, 2016; Sever, Ulubey, Toraman \& Türe, 2014) and students have higher tendency to not participate in mathematics lectures (Sever et al., 2014). In addition to these results, a meaningful relationship between gender and participation has been determined (Archer, Halsall \& Hollingworth, 2007; Furrer \& Skinner, 2003). On the other hand, it has been concluded that as the class level increase, the secondary school students' motivation and participation levels decrease (Güvenç \& Koç, 2016). The results of researches also show that active learning leads more participation, increases permanent knowledge, curiosity and inquiry skills of the students and there is a significant positive relationship between participation and academic achievement (Adiyaman, 2008; Bush, Ladd \& Herald, 2006; Carini, Kuh \& Klein, 2006; Coates, 2005; Gunuc, 2014; Park, 2005).

As a result, it can be said that if the students participate effectively in the learning process, they have a more meaningful learning experience and enjoy more about what they have learned. However, the students who are passive and do not have an interest in the lectures tend to forget what they have learnt more quickly, become more bored and boycott/disrupt the lectures. Hence, it is possible to say that if there is effective participation in the learning process, there will be a high increase in learning success.

\subsection{Motivation}

Motivation is derived from Latin word Movere which mean "to move". Motivation is expressed as an internal state that leads us to action, pushes us in specific directions and makes us continue to practice certain actions (Çöğür, 2010; Ormrod, 2016). Motivation is defined as goals, beliefs, and values that affect the activities, achievements, and needs of individuals (Guthrie, Wigfield, Metsala, \& Cox, 1999; Guthrie \& Wigfield, 1997). Motivation is a phenomenon that has the student's perceptions of himself and his environment as a source, makes the students focus on the educational activity presented to him, and gives them the determination to complete it (Viau, 2015, p.57). Motivation is often described as an internal condition that arouses, directs and sustains behaviour (Wolfolk Hoy, 2015). Psychologists working on motivation focus on the following five core questions (Graham \& Weiner, 1996; Pintrich, Marx \& Boyle, 1993):

- How do people make choices about their behaviours?

- How long does it take to get started?

- What is the level of participation intensity in a selected activity?

- What are the factors that cause the individual to give up or continue with perseverance?

- What does the student think and feel when dealing with an activity?

Motivation is a triggering power for learning. The lack of motivation means that there is no action and therefore difficulty in reaching the desired goal (Demir \& Budak, 2016). Motivation is an important factor in the effectiveness of learning and teaching processes since it is not only a significant factor in students' achievements but also it gives energy and ensures that behaviour is voluntary. In addition, it has a significant impact on students' problem-solving abilities and the ability to maximize the performance they have shown when they encounter a problem (Kutu \& Sözbilir, 2011; Yaman \& Dede, 2007).

Deci, Vallerand, Pelletier and Ryan (1991) deal with motivation both internally and externally and see internal-external motivation as a harmonious whole. While emphasizing the need to develop intrinsic motivation, it is emphasized that students who are not internally motivated by teachers, can also learn. Reinforcements and awards are external motivation tools; i.e. money, points or sometimes grades. Intrinsic motivation involves self-determined activities that were done for himself. The individual wants to do it for himself rather than expecting any award. In such motivated individuals, rewarding is done on their own, and their self-regulation competency is at the highest level (Akpınar, Batdi \& Dönder, 2013). Intrinsic motivation is a strong factor in learning. In other words, if an individual is intrinsically motivated, his learning will be of high quality. In this type of motivation, control is on the individual's hand and the individual directs learning on his own choices (Schick \& Schewedes, 1999).

It has been found that teaching is not healthy and meaningful without motivation. Students with high achievement motivation tend to work hard to learn. In contrast, those with low motivation are reluctant to learn or they feel desperate since they show themselves as if they learn (Ceylan, Sağırekmekçi, Tatar \& Bilgin, 2016). There are also many research results regarding a strong relation between motivation and achievement (Areepattamannil, Freeman \& Klinger, 2011, Ceylan et al., 2016, Othman \& Leng, 2011). 
When literature related to motivation is reviewed, it has been found that female secondary school students are more motivated than that of male students (Uzun \& Keles, 2010) in collaborative work, participation and communication. It has also been found that secondary school students' use of computers at home, watching science-related TV programs, and following scientific journals have a positive effect on the science learning motivation (Inel-Ekici, Kaya \& Mutlu, 2004). In a similar study, it was determined that the motivation levels of secondary school students for science learning vary according to the class level, the number of books in their home and the weekly study period of the science courses (Yenice, Saydam \& Telli, 2012). The results of research reveal that interactive practices and different approaches are beneficial in motivating learners, in the learning and teaching process, and in this process both teachers and other students are positive reflections on motivation (Wentzel, Battle, Russell \& Looney, 2010). Among the listening, speaking, reading, and writing skills of the students, speaking and reading skills have been shaped by internal motivation at most (Lucas et al., 2010). Keifer, Alley, and Ellerbrock (2015) found that teacher and peer support significantly influenced motivation, class participation, and the sense of belonging to the school. Also, in the same study, it was seen that if the teachers could meet the needs of the students in the classroom, the students' motivation, participation and belonging to the school were affected positively. Lee, Hayes, Seitz, Distefano and O'Connor (2016) have found that participation has mediated the relationship between intrinsic motivation and science achievement, whereas external motivation has had no relation to participation and science achievement.

In his study (2011), Carreira reached the conclusion that intrinsic motivation began to decrease as students passed from the 3rd to the 6th grade. In addition, he has shown that curiosity, interest in foreign countries and entertaining teaching methods have positive effects on students' motivation to learn English. Matteson, Swarthout and Zientek (2011) found that teachers believe that motivation is important for learning, new teachers have not identified teaching methods as motivators, teachers have difficulty in determining motivation strategies for pedagogy and curriculum, there are some teachers who use concrete rewards for motivation and the concept of motivation needs to be emphasized more in teacher training programs.

These studies show that motivation is a very important factor in a student's academic life. Two kinds of motivations are mentioned, intrinsic and extrinsic. Particularly, motivation is the most important factor in secondary school students' participation in class activities, their sense of belonging to school and supporting their self-confidence. Due to these conclusions, teachers should be well-informed about their students and should include activities that will attract students and meet their needs in the classroom. Teachers should take measures to increase the students' motivation in order to increase their participation in the classroom. These are possible, sometimes in the form of awards and sometimes with the appreciation of positive behaviours.

In this study, we will try to answer the following questions:

- How is the effective participation of secondary school students?

- Does the effective participation of secondary school students reveal significant difference according to gender?

- Does the effective participation of secondary school students reveal significant difference according to class?

- Does the effective participation of secondary school students reveal significant difference according to courses?

- How are the motivation of secondary school students?

- Does the motivation of secondary school students reveal significant difference according to gender?

- Does the motivation of secondary school students reveal significant difference according to year of study?

- Does the motivation of secondary school students reveal significant difference according to courses?

- Finally, is there a meaningful relationship between the level of effective participation and the motivation of secondary school students?

\section{Method}

\subsection{Research Design}

This research has employed a survey. A survey provides quantitative description of trends, attitudes, or opinions in a population through studies on a selected sample from that population (Creswell, 2013).

\subsection{Participants}

The population of this survey consists of 6th, 7th and 8th grade secondary school students in the central districts of Erzurum and Iğdır. The sample of the study is composed of 251 secondary school students in the schools determined according to the easily accessible sampling method. The distribution of the sample according to the variables is given in Table 1. 
Table 1. Distribution of the Sample by Variables

\begin{tabular}{|c|c|c|c|c|}
\hline Variables & & & $\mathrm{n}$ & $\%$ \\
\hline \multirow[t]{3}{*}{ Gender } & Female & & 171 & 68.1 \\
\hline & Male & & 80 & 31.9 \\
\hline & & Total & 251 & 100.0 \\
\hline \multirow[t]{4}{*}{ Class } & 6th Grade & & 86 & 34.3 \\
\hline & 7th Grade & & 81 & 32.3 \\
\hline & 8th Grade & & 84 & 33.5 \\
\hline & & Total & 251 & 100.0 \\
\hline \multirow[t]{4}{*}{ Courses } & Turkish & & 84 & 33.5 \\
\hline & Mathematics & & 83 & 33.1 \\
\hline & English & & 84 & 33.5 \\
\hline & & Total & 251 & 100.0 \\
\hline
\end{tabular}

Table 1 shows that $171(68.1 \%)$ of the 251 secondary school students are female and $80(31.9 \%)$ are male. According to the class, $86(34.3 \%)$ students are in 6th grade, $81(32.3 \%)$ are in 7 th grade and remaining $84(33.5 \%)$ are in 8th grade. $84(33.5 \%)$ of the student participation information was gathered from Turkish, 83 (33.1\%) from Mathematics and remaining 84 (33.5\%) from English courses.

\subsection{Instruments}

In this study, the data was collected by applying two different scales to determine the level of motivation and effective participation of students.

\subsubsection{Effective Participation Scale}

The scale was developed by Güvenç (2015) to determine the engagement and disaffection of high school students. The scale has been developed through two separate studies. In the first study, an effective participation scale was developed for high school students, whereas in the second study, the improved scale was adapted to secondary school students. The scale consists of 16 items with 4 likert types. These are "Absolutely Not True" 1; "Mostly Not True" 2; "Mostly True" 3; "Definitely True" will be 4 points. The scale consists of 4 subdimensions as "Behavioural Engagement", "Emotional Engagement", "Behavioural Disaffection" and "Emotional Disaffection". The Cronbach Alpha reliability coefficient of 8-item engagement section of the scale is 0,81 and the Cronbach Alpha reliability coefficient of 8-item of disaffection section is 0,77 , whereas the Cronbach Alpha reliability coefficient of engagement section of this study is 0,79 and Cronbach Alpha reliability coefficient of disaffection section of this study is 0,73 .

\subsubsection{Intrinsic-Extrinsic Motivation Scale (IEMS)}

The scale has been originally developed by Harter (1981) consisting of 36 items. Later, Lepper, Corpus and Iyengar (2005) reorganized and decreased the number of items from 36 to 33. It has been adapted to Turkish by Colak and Curık (2015). The scale consists of two subscales as internal motivation and external motivation and three subdimensions of for each subscale. Subdimensions of intrinsic motivation subscale are "expertise", "curiosity", "challenge" and extrinsic motivation subscale subdimensions are "easy work", "dependence on teacher" and "pleasing teacher". The scale consists of 28 items with 5 likert types. These are (1) "Not at all valid"; (2) "Rarely valid"; (3) "Sometimes valid"; (4) "Fairly valid"; (5) "Completely valid". When the scale reliability studies were examined in subdimensions, Cronbach Alpha coefficients for extrinsic motivation ranged from 0,60 to 0,84 while Cronbach Alpha coefficients for intrinsic motivation ranged from 0,69 to 0,78. The Cronbach Alpha coefficient of the total scores of extrinsic motivation subscale was 0,76 , and the total score of intrinsic motivation subscale was found to be 0,86 . The Cronbach Alpha reliability coefficient calculated for this study was 0,72 for extrinsic motivation and 0,89 for intrinsic motivation.

\subsection{Data Analysis}

MANOVA test was performed in order to understand whether effective participation and motivation of secondary school students differ according to gender, class and course variables. Before conducting MANOVA analysis, the assumptions of the analysis were checked. The followings were tested, respectively (a) independence of observations, (b) normal distribution of dependent variables for multiple and singular cases, (c) homogeneity of variances of dependent variables and covariances by each other. In all statistical tests $\alpha=, 05$ significance level was used. By 
Bonferroni alpha correction, the 0,05 significance level was divided by the number of dependent variables and the corrected alpha levels for each dependent variable test result were used so that the total statistical error rate does not exceed 5\% (Pallant, 2007). In order to examine the practical effect of the statistically significant differences between the groups, Cohen $\mathrm{d}$ and partial eta-square effect size values were calculated. The relationship between the two variables was analyzed via Pearson Correlation Coefficient.

\section{Results}

Descriptive statistics of the effective participation levels of secondary school students have been calculated and shown in Table 2.

Table 2. Descriptive Statistics of Students' Effective Participation Levels

\begin{tabular}{llll}
\hline Subdimensions & $\mathrm{n}$ & $\bar{X}$ & $\mathrm{sd}$ \\
\hline Behavioural Engagement & 251 & 11.81 & 2.95 \\
Emotional Engagement & 251 & 12.40 & 2.69 \\
$\quad$ Total Engagement & 251 & 24.21 & 5.03 \\
Behavioural Disaffection & 251 & 7.75 & 2.50 \\
Emotional Disaffection & 251 & 7.17 & 2.80 \\
Total Disaffection & 251 & 14.92 & 4.66 \\
\hline
\end{tabular}

Table 2 depicts that when the arithmetic average scores of students' effective participation are analyzed, it is found that the subdimension with the highest arithmetic average $(\bar{X}=12.4)$ is the emotional engagement and the one with the lowest arithmetic average is the emotional disaffection. When the arithmetic average score of total engagement $(\bar{X}=24.21)$ and total disaffection ( $\bar{X}=14.92)$ are compared, it can be said that effective participation level of the students is positive.

Descriptive statistics of the effective participation levels of secondary school students according to gender have been given in Table 3.

Table 3. Descriptive Statistical Results of Students' Effective Participation Levels According to Gender Variable

\begin{tabular}{|c|c|c|c|c|}
\hline Subscales & Gender & $\mathrm{n}$ & $\bar{X}$ & sd \\
\hline \multirow{2}{*}{ Engagement } & Female & 171 & 24.92 & 4.85 \\
\hline & Male & 80 & 22.68 & 5.08 \\
\hline \multirow{4}{*}{ Disaffection } & & 251 & 24.21 & 5.03 \\
\hline & Female & 171 & 14.33 & 4.51 \\
\hline & Male & 80 & 16.19 & 4.75 \\
\hline & & 251 & 14.92 & 4.66 \\
\hline
\end{tabular}

The results of the MANOVA analysis on whether effective participation levels of secondary school students differ according to gender have been given in Table 3 .

Table 4. Results of Manova Analysis on the Differences between the Mean Scores of Effective Participation Levels of Secondary School Students According to Gender Variable

\begin{tabular}{llllllc}
\hline & Wilks' $\Lambda$ & $F$ & Hypothesis $d f$ & Error $d f$ & $p$ & $\eta^{2}$ \\
\hline Gender & .946 & 7.030 & 2 & 248 & .001 & .054 \\
\hline
\end{tabular}

A one-way MANOVA was conducted to determine the gender effect on the effective participation levels of secondary school students. The result of Box's $M$ test $\left(\mathrm{F}_{3-549606,251}=1,230, \mathrm{p}=.749\right)$ indicates homogeneity of covariance matrices. The results of the Wilks Lambda Test reveal that the linear combinations of subscales for effective participation of secondary school students according to gender show a significant difference (Wilk's $\Lambda$ $\left.=.946, \mathrm{~F}_{(2,248)}=7,030, \mathrm{p}=.001, \mathrm{\eta} 2=.054\right)$. According to the results, scores of the linear component obtained from the scores of subscales of scale differ between male and female students.

According to Cohen (1988) classification, $\eta^{2}=.01$ is indicated as "small", $\eta^{2}=.06$ as "moderate", and $\eta 2=.14$ and higher as "large". In this study, the partial eta square of .054 for gender indicates moderate effect according to 
Cohen's classification. In other words, $5 \%$ of the variance of the scores obtained from the effective participation subscale scores can be explained by gender.

It has been checked for which dependent variables there is a significant difference and the results have been shown in Table 5.

Table 5. Conclusions on the Differences between Students' Effective Participation Subscales Scores According to gender Variable

\begin{tabular}{lllllllll}
\hline Source of variance & Dependent Variable & $\begin{array}{l}\text { Sum } \\
\text { Squares }\end{array}$ & of & df & $\begin{array}{l}\text { Mean } \\
\text { Square }\end{array}$ & F & Sig. & $\eta^{2}$ \\
& Engagement & 275.665 & 1 & 275.665 & 11.365 & .001 & .044 \\
\multirow{2}{*}{ Eender } & Disaffection & 187.374 & 1 & 187.374 & 8.907 & .003 & .035 \\
& Engagement & 6039.562 & 249 & 24.255 & & & \\
\multirow{2}{*}{ Total } & Disaffection & 5238.187 & 249 & 21.037 & & & \\
& Engagement & 153398.000 & 251 & & & & \\
& Disaffection & 61332.000 & 251 & & & & \\
\hline
\end{tabular}

* The new level of significance according to Bonferroni correction is, 025 .

Table 5 depicts that there is a significant difference between the engagement subscale and the disaffection subscale $(\mathrm{F}$ engagement (1-249) $=11,365, \mathrm{p}=.001, \mathrm{\eta} 2=.044 ; \mathrm{F}$ disaffection (1-249) $=8,907, \mathrm{p}=.003, \mathrm{\eta} 2=.035)$. In this study, the effect size $(\eta 2=.044)$ calculated between the gender variable and the engagement subscale and the effect size $(\eta 2=.035)$ calculated between the gender variable and the disaffection subscale indicate a moderate effect on Cohen's classification. In other words, $4 \%$ of the variance of the scores obtained from the engagement subscale and $4 \%$ of the variance of the scores obtained from the disaffection subscale can be explained by gender variable. When the average scores are examined, it is found that female students $(\bar{X}=24,09)$ engaged more than male students $(\bar{X}$ $=22,68)$ and it is understood that female students $(\bar{X}=14.33)$ are less disaffected when compared to male students $(\bar{X}=16.19)$.

The results of the MANOVA analysis on whether the effective participation levels of secondary school students differ according to the class have been given in Table 6 .

Table 6. Results of Manova Analysis on the Difference between Average Effective Participation Scores of the Secondary School Students by Class Variable

\begin{tabular}{llllll}
\hline & Wilks' $\Lambda$ & $F$ & Hypothesis $d f$ & Error $d f$ & $p$ \\
\hline Class & .971 & 1.805 & 4 & 494 & .127 \\
\hline
\end{tabular}

A one-way MANOVA was conducted to determine the gender effect on the effective participation levels of secondary school students. The result of Box's $\mathrm{M}$ test $\left(\mathrm{F}_{6-1508643}=1,510, \mathrm{p}=.170\right)$ indicates homogeneity of covariance matrices. The results of the Wilks Lambda Test reveal that the linear combinations of subscales for effective participation of secondary school students according to class variable show no significant difference (Wilk's $\Lambda=.971$, $\left.\mathrm{F}_{(4,494)}=1,805, \mathrm{p}=.127\right)$. According to the results, the scores of the linear component obtained from the scores belonging to the sub-dimensions of the scale show no difference between 6., 7. and 8th grade students.

Table 7 provides descriptive statistics on the effective participation levels of the secondary school students according to the course variable.

Table 7. Descriptive Statistical Results of Students' Effective Participation Levels According to Course Variable

\begin{tabular}{|c|c|c|c|c|}
\hline Subscales & Course & $\mathrm{n}$ & $\bar{X}$ & sd \\
\hline \multirow{3}{*}{ Engagement } & Turkish & 86 & 24,18 & 5,57 \\
\hline & Mathematics & 81 & 23,16 & 4,54 \\
\hline & English & 84 & 25,27 & 4,74 \\
\hline \multirow{5}{*}{ Disaffection } & & 251 & 24,21 & 5,03 \\
\hline & Turkish & 86 & 14,37 & 4,39 \\
\hline & Mathematics & 81 & 16,40 & 4,70 \\
\hline & English & 84 & 14,02 & 4,58 \\
\hline & & 251 & 14,92 & 4,66 \\
\hline
\end{tabular}


The results of the MANOVA analysis on whether the effective participation levels of secondary school students differ according to the course variable are given in Table 8 .

Table 8. Results of Manova Analysis on the Difference between Average Effective Participation Scores of the Secondary School Students by Course Variable

\begin{tabular}{lllllll}
\hline & Wilks' $\Lambda$ & $F$ & Hypothesis $d f$ & Error $d f$ & $p$ & $\eta^{2}$ \\
\hline Course & .940 & 3.871 & 4 & 494 & .004 & .030 \\
\hline
\end{tabular}

A one-way MANOVA was conducted to determine the course effect on the effective participation levels of secondary school students. The result of Box's $\mathrm{M}$ test $\left(\mathrm{F}_{6-1531582,245}=1,938, \mathrm{p}=.071\right)$ indicates homogeneity of covariance matrices. The results of the Wilks Lambda Test reveal that the linear combinations of subscales for effective participation of secondary school students according to course variable show a significant difference (Wilk's $\Lambda=.940, \mathrm{~F}_{(4,494)}=3,871, \mathrm{p}=.004, \mathrm{\eta}^{2}=.030$ ). According to the results, the scores of the linear component obtained from the scores belonging to the sub-dimensions of the scale show a difference between Turkish, Mathematics and English courses. In this study, the partial eta square of .030 for course variable indicates moderate effect according to Cohen's classification. In other words, $3 \%$ of the variance of the scores obtained from the effective participation subscale scores can be explained by course.

It has been checked for which dependent variables there is a significant difference and the results have been shown in Table 9.

Table 9. Conclusions on the Differences between Students' Effective Participation Subscales Scores According to Course Variable

\begin{tabular}{llllllll}
\hline Source & Dependent Variable & Sum of Squares & df & Mean Square & F & Sig. & $\eta^{2}$ \\
\hline Course & Engagement & 187.239 & 2 & 93.620 & 3.789 & .024 & .030 \\
& Disaffection & 274.170 & 2 & 137.085 & 6.600 & .002 & .051 \\
\multirow{3}{*}{ Error } & Engagement & 6127.988 & 248 & 24.710 & & & \\
& Disaffection & 5151.391 & 248 & 20.772 & & & \\
& Engagement & 153398.000 & 251 & & & & \\
& Disaffection & 61332.000 & 251 & & & & \\
\hline
\end{tabular}

* The new level of significance according to Bonferroni correction is, 025 .

Table 9 depicts that there is a significant difference between the engagement subscale and the disaffection subscale $\left(\mathrm{F}\right.$ Engagement $(2-248)=3,789, \mathrm{p}=.024, \mathrm{\eta}^{2}=.030 ; \mathrm{F}$ Disaffection (2-249) $\left.=6,600, \mathrm{p}=.002, \mathrm{\eta}^{2}=.051\right)$ when effective participation levels of secondary school students according to course variable is analyzed. In this study, the effect size ( $\mathrm{n} 2=.030)$ calculated between the course variable and the engagement subscale and the effect size $(\eta 2=.051)$ calculated between the course variable and the disaffection subscale indicate a moderate effect on Cohen's classification. In other words, $3 \%$ of the variance of the scores obtained from the engagement subscale and $5 \%$ of the variance of the scores obtained from the disaffection subscale can be explained by course variable.

According to the results of post hoc test, which was conducted to determine which factor levels provide the differences in the subscales, it was observed that there was a significant difference in favor of English lesson when the mean scores of English lesson $(\bar{X}=25,27)$ and Mathematics lesson $(\bar{X}=23,16)$ were compared based on engagement subscale; there was a significant difference in favor of Mathematics lesson when the mean scores of Mathematics lesson $(\bar{X}=16,40)$ and English lesson $(\bar{X}=14,02)$, and Mathematics lesson $(\bar{X}=16,40)$ and Turkish lesson $(\bar{X}=14,37)$ based on disaffection subscale. In other words, the secondary school students engage more in English lesson then Mathematics lesson and they are more disaffected in Mathematics lesson compared to Turkish and English lessons.

Table 10 provides descriptive statistics on the motivation scores of the secondary school students. 
Table 10. Descriptive Statistics of Students' Motivation Scores

\begin{tabular}{lllll}
\hline Motivation & Subdimensions & $\mathrm{n}$ & $\bar{X}$ & $\mathrm{sd}$ \\
\hline Extrinsic Motivation & Easy work & 251 & 11.48 & 3.31 \\
& Pleasing teacher & 251 & 8.97 & 3.45 \\
& Dependence on teacher & 251 & 19.50 & 4.30 \\
Intrinsic Motivation & Challenge & 251 & 21.66 & 5.96 \\
& Curiosity & 251 & 22.63 & 5.07 \\
& Expertise & 251 & 18.05 & 4.62 \\
\hline
\end{tabular}

Table 10 showed that secondary school students" "dependence on teacher" subdimension of extrinsic motivation subscale the highest mean score $(\bar{X}=19,50)$ and "pleasing teacher" subdimension has the lowest mean score $(\bar{X}$ $=8,97)$. When intrinsic motivation subscales' subdimensions were compared, it was observed that the highest mean score belonged to "curiosity" and the lowest belonged to "expertise".

Table 10 provides descriptive statistics on the motivation scores of the secondary school students according to gender variable.

Table 11. Descriptive Statistics of Secondary School Students' Motivation Scores According to Gender Variable

\begin{tabular}{llllll}
\hline Subscales & Gender & $\mathrm{n}$ & $\bar{X}$ & $\mathrm{sd}$ \\
\hline \multirow{2}{*}{ Extrinsic Motivation } & & Female & 171 & 40,21 & 7,32 \\
& & Male & 80 & 39,38 & 7,62 \\
& \multirow{3}{*}{ Total } & & 251 & 39,95 & 7,41 \\
Intrinsic Motivation & & Female & 171 & 62,85 & 12,41 \\
& & Male & 80 & 61,21 & 14,02 \\
& & & 251 & 62,33 & 12,94
\end{tabular}

The results of MANOVA analysis showing whether the secondary school students' motivation scores defer according to gender are depicted in Table 12.

Table 12. Results of Manova Analysis on the Difference between Mean Motivation Scores of the Secondary School Students by Gender Variable

\begin{tabular}{llllll}
\hline & Wilks' $\Lambda$ & $F$ & Hypothesis $d f$ & Error $d f$ & $p$ \\
\hline Gender & .994 & .730 & 2 & 248 & .483 \\
\hline
\end{tabular}

A one-way MANOVA was conducted to determine the gender effect on the motivation of secondary school students. The result of Box's $\mathrm{M}$ test $\left(\mathrm{F}_{3-549606,251}=, 630, \mathrm{p}=.596\right)$ indicates homogeneity of covariance matrices. The results of the Wilks Lambda Test reveal that the linear combinations of subscales for motivation of secondary school students according to course variable showed no significant difference (Wilk's $\Lambda=.994, \mathrm{~F}_{(2,248)}=, 630$, $\mathrm{p}=.483$ ). The scores of the linear component obtained from the scores belonging to the sub-dimensions of the scale showed no difference between female and male secondary school students.

Table 13 provides descriptive statistics on the motivation scores of the secondary school students according to class variable.

Table 13. Descriptive Statistics of Secondary School Students' Motivation Scores According to Class Variable

\begin{tabular}{|c|c|c|c|c|}
\hline Subscale & Class & $\mathrm{n}$ & $\bar{X}$ & $\mathrm{sd}$ \\
\hline \multirow{3}{*}{ Extrinsic Motivation } & 6 th grade & 86 & 38,74 & 8,10 \\
\hline & 7 th grade & 81 & 41,07 & 7,54 \\
\hline & 8 th grade & 84 & 40,10 & 6,37 \\
\hline \multirow{5}{*}{ Intrinsic Motivation } & & 251 & 39,95 & 7,41 \\
\hline & 6 th grade & 86 & 64,76 & 12,84 \\
\hline & 7 th grade & 81 & 65,15 & 10,32 \\
\hline & 8 th grade & 84 & 57,12 & 13,84 \\
\hline & & 251 & 62,33 & 12,94 \\
\hline
\end{tabular}


The results of MANOVA analysis showing whether the secondary school students' motivation scores defer according to class are depicted in Table 14.

Table 14. Results of Manova Analysis on the Difference between Average Motivation Scores of the Secondary School Students by Class Variable

\begin{tabular}{lllllll}
\hline & Wilks' $\Lambda$ & $F$ & Hypothesis $d f$ & Error $d f$ & $p$ & $\eta^{2}$ \\
\hline Class & .902 & 6.549 & 4 & 494 & .000 & .050 \\
\hline
\end{tabular}

A one-way MANOVA was conducted to determine the class effect on the motivation of secondary school students. The result of Box's $\mathrm{M}$ test $\left(\mathrm{F}_{6-1508643}=2,477, \mathrm{p}=.210\right)$ indicates homogeneity of covariance matrices. The results of the Wilks Lambda Test reveal that the linear combinations of subscales for motivation of secondary school students according to class variable show a significant difference (Wilk's $\Lambda=.902, \mathrm{~F}_{(4,494)}=6,549, \mathrm{p}=.000, \mathrm{\eta}^{2}=.050$ ). According to the results, the scores of the linear component obtained from the scores belonging to the sub-dimensions of the scale show a difference between $6^{\text {th }}, 7^{\text {th }}$ and $8^{\text {th }}$ grades. In this study, the partial eta square of .050 for class variable indicates moderate effect according to Cohen's classification. In other words, $5 \%$ of the variance of the scores obtained from the motivation ssubscale scores can be explained by class.

It was checked for which dependent variables there is a significant difference and the results are shown in Table 15.

Table 15. Descriptive Statistics of Secondary School Students' Mean Motivation Scores According to Class Variable

\begin{tabular}{llllllll}
\hline Source & Dependent Variable & Sum of Square & df & Mean Square & F & Sig. & $\eta^{2}$ \\
\hline Class & Extrinsic Motivation & 229,161 & 2 & 114,580 & 2,105 &, 124 & \\
& Intrinsic Motivation & 3430,307 & 2 & 1715,154 & 11,065 &, 000 & \multirow{2}{*}{082} \\
Error & Extrinsic Motivation & 13499,166 & 248 & 54,432 & & & \\
& Intrinsic Motivation & 38440,904 & 248 & 155,004 & & & \\
Total & Extrinsic Motivation & 414289,000 & 251 & & & & \\
& Intrinsic Motivation & 1016910,000 & 251 & & & & \\
\hline
\end{tabular}

* The new level of significance according to Bonferroni correction is, 025 .

Table 15 depicts that there is a significant difference between intrinsic motivation subscale while there is no significant difference between extrinsic motivation subscale ( $\mathrm{F}$ Extrinsic Motivation (2-248) $=2,105, \mathrm{p}=.124 ; \mathrm{F}$ Intrinsic Motivation $\left.(2-249)=11,065, \mathrm{p}=.000, \mathrm{\eta}^{2}=.082\right)$. when motivation of secondary school students according to class variable was analyzed. The effect size $(\mathrm{\eta} 2=.082)$ calculated between the class variable and the intrinsic motivation subscale indicate a moderate effect on Cohen's classification. In other words, $8 \%$ of the variance of the scores obtained from the intrinsic motivation subscale can be explained by course variable.

According to the results of post hoc test, which was conducted to determine which factor levels provide the differences in the subscales, it was observed that there was a significant difference in favor of $6^{\text {th }}$ grade when the mean scores of $6^{\text {th }}$ grade $(\bar{X}=64,76)$ and $8^{\text {th }}$ grade $(\bar{X}=57,12)$ were compared based on intrinsic motivation subscale; there was a significant difference in favor of $7^{\text {th }}$ grade when the mean scores of $7^{\text {th }}$ grade $(\bar{X}=65,15)$ and $8^{\text {th }}$ grade $(\bar{X}=57,12)$ based on intrinsic motivation subscale. In other words, $6^{\text {th }}$ and $7^{\text {th }}$ grade the secondary school students have higher motivation than $8^{\text {th }}$ grade students.

Table 16 provides descriptive statistics on the motivation scores of the secondary school students according to course variable.

Table 16. Descriptive statistics of Secondary School Students' Average Motivation Scores According to Course Variable

\begin{tabular}{|c|c|c|c|c|}
\hline Subscale & Course & $\mathrm{n}$ & $\bar{X}$ & sd \\
\hline \multirow{3}{*}{ Extrinsic Motivation } & Turkish & 86 & 39,37 & 8,51 \\
\hline & Mathematics & 81 & 40,84 & 6,99 \\
\hline & English & 84 & 39,64 & 6,60 \\
\hline \multirow{4}{*}{ Intrinsic Motivation } & & 251 & 39,95 & 7,41 \\
\hline & Turkish & 86 & 62,48 & 13,32 \\
\hline & Mathematics & 81 & 62,39 & 10,68 \\
\hline & English & 84 & 62,12 & 14,64 \\
\hline & & 251 & 62,33 & 12,94 \\
\hline
\end{tabular}


The results of MANOVA analysis showing whether the secondary school students' motivation scores defer according to course are depicted in Table 17.

Table 17. Results of Manova Analysis on the Difference between Average Motivation Scores of the Secondary School Students by Course Variable

\begin{tabular}{llllll}
\hline & Wilks' $\Lambda$ & $F$ & Hypothesis $d f$ & Error $d f$ & $p$ \\
\hline Course & .992 & 4.74 & 4 & 494 & .755 \\
\hline
\end{tabular}

A one-way MANOVA was conducted to determine the course variable effect on the motivation of secondary school students. The result of Box's $\mathrm{M}$ test $\left(\mathrm{F}_{6-1531582,245}=2,434, \mathrm{p}=.240\right)$ indicates homogeneity of covariance matrices. The results of the Wilks Lambda Test reveal that the linear combinations of subscales for motivation of secondary school students according to course variable showed no significant difference (Wilk's $\Lambda=.992, F_{(4,494)}=4,74$, $\mathrm{p}=.755$ ). The scores of the linear component obtained from the scores belonging to the sub-dimensions of the scale showed no difference between Turkish, Mathematics and English lessons.

Pearson Product-Moment Correlation Coefficient is used to calculate the relationship between effective participation levels and motivation of secondary school students and results are shown in Table 18.

Table 18. Results of Correlation Analysis of the Relationship between Motivation and Effective Participation Levels of Secondary School Students

\begin{tabular}{|c|c|c|c|c|c|}
\hline & & Engagement & Disaffection & $\begin{array}{l}\text { Intrinsic } \\
\text { Motivation }\end{array}$ & $\begin{array}{l}\text { Extrinsic } \\
\text { Motivation }\end{array}$ \\
\hline \multirow[t]{3}{*}{ Engagement } & Pearson & & $-.466 * *$ & $.442 * *$ & .023 \\
\hline & Correlation & & & & \\
\hline & Sig. & & .000 & .000 & .716 \\
\hline \multirow[t]{3}{*}{ Disaffection } & Pearson & $-.466 * *$ & & $-.377 * *$ & -.017 \\
\hline & Correlation & & & & \\
\hline & Sig. & .000 & & .000 & .787 \\
\hline Intrinsic & Pearson & $.442 * *$ & $-.377 * *$ & & .075 \\
\hline \multirow[t]{2}{*}{ Motivation } & Correlation & & & & \\
\hline & Sig. & .000 & .000 & & .234 \\
\hline Extrinsic & Pearson & .023 & -.017 & .075 & \\
\hline \multirow[t]{2}{*}{ Motivation } & Correlation & & & & \\
\hline & Sig. & .716 & .787 & .234 & \\
\hline
\end{tabular}

As shown in Table 18,

- there is a significant positive correlation between engagement subscale of effective participation scale and intrinsic motivation subscale of motivation scale of secondary school students $[\mathrm{r}=-.442, \mathrm{n}=251, \mathrm{p}<.01]$,

- there is a significant negative correlation between engagement subscale and disaffection subscale of effective participation scale $[\mathrm{r}=-.446, \mathrm{n}=251, \mathrm{p}<.01]$, and

- there is a significant negative correlation between disaffection subscale and intrinsic motivation subscale $[\mathrm{r}=-.377, \mathrm{n}=251, \mathrm{p}<.01]$

\section{Discussion}

It is found that the "Emotional Engagement" dimension has the highest arithmetic average and the "Emotional Disaffection" subdimension has the lowest. This can be interpreted as the secondary school students' effective participation levels are positive. Güvenç and Koç (2016) have also found similar results. Considering the research results (Furrer \& Skinner, 2003; Wang \& Holcombe, 2010) that say the high participation in learning process will lead higher achievement and lower education leaving, the results of this study can give clues that these students' achievement will be higher since their participation levels are positive.

When results about engagement and disaffection subscales are analyzed, it is determined that the female secondary school students are more engaged than the male students, while male students are more disaffected than the female 
students. Kinzie et al. (2007) reached the conclusion that female college students spend more time in preparing presentations about courses, projects and group works and they communicate more with their teachers. It was stated that this is due to the fact that male students are more likely to work independently.

It has been found that the class variable has no effect on effective participation of secondary school students. If teachers increase the students' motivation and design the student work so that they will encourage effective participation throughout the teaching process, the class variable will be tolerated.

When secondary school students' engagement subscale average scores are examined according to courses especially for English and Mathematics, it is found that there is a significant difference in favor of English. When disaffection subscale average scores are considered, it is found that there is a significant difference in favor of Mathematics. In other words, secondary school students are more engaged in English than Mathematics and they are more disaffected in Mathematics when compared to English and Turkish. When literature is reviewed, it is understood that most of the students experience math anxiety. Hannula (2005) specified that people either love Mathematics or hate it. In this context, he mentioned that mathematical thinking and learning are intertwined with emotional approach to mathematics. Therefore, the students' disaffection to Mathematics may be due to their attitudes to Mathematics. Furtherly, this can be interpreted as the reason for their low engagement in Mathematics.

The results based on extrinsic motivation subscale show that the secondary school students have the highest participation level in "dependence on teacher" subdimension and the lowest participation in "pleasing teacher" subdimension. When the results for intrinsic motivation subscale are analyzed, it has been found that their participation level is the highest for "curiosity" subdimension and the lowest for "expertise" subdimension.

It has been found that the gender variable has no effect on the motivation of secondary school students. As there are researches (Rusillo \& Airas, 2004; Tariq, Hussain \& Mahmood, 2011; Uluçay \& Güven, 2017) that support the foundings of this study, (Colak \& Cirik, 2015; Yerlikaya, 2014) found that female students had more internal motivation scores than male students and (Karataş \& Erden, 2012; Lai, Chan \& Wong, 2006) found that male students have higher internal motivation scores than female ones. The contradiction between these studies can be interpreted as the fact that the different variables that students have in each school have different effects on the male and female students, which in turn influence their motivation in different ways.

It has been determined that the class variable showed significant differentiation of the internal motivation of secondary school students. When the internal motivation of 6th and 8th grade secondary school students are compared, it is found that there is a significant difference in favor of the 6th grade students. When that of 7 th and 8th are compared, the difference is in favor of the 7th grade students. These can be interpreted as internal motivations of 6th and 7th grade students are higher than that of 8th grade students. This result was also found in similar research (Corpus, McClintic-Gilbert \& Hayenga, 2006; Midgley, Feldlaufer \& Eccles, 1989; Cleary \& Chen, 2009). In related research, it was noted that the rise of students' grade changes the motives and participation levels of the students in negative direction. Ryan and Patrick (2001) stated that this negative change observed in secondary school ages may be due to their negative perceptions about themselves and their schools. Tolunay-Ates (2016) explained this result is because 8th grade students need more support in this period and the fact that they have to join the centralized examination also influence this result.

This study's findings show that the class variable has no meaningful influence on the external motivation of secondary school students. There are similar findings in the literature (Corpus et al., 2006, Lepper, Corpus \& Iyengar, 2005). In the related research, it was shown that external motivation does not show a great change after passing the 4th grade. Lepper et al. (2005) listed the causes of low motivation as the class level increases; increasing school control with age, decreasing options and decreasing student autonomy.

It has been determined that there is no significant difference between the motivation of the secondary school students and the course variable. The fact that there is no significant difference between Turkish, Mathematics and English lessons and the motivations of the students may be due to the teacher, previous experiences and other factors in the teaching process.

The main finding of this study is that there is a significant positive correlation between engagement and internal motivation and a significant negative correlation between engagement and disaffection, and a significant negative correlation between disaffection and internal motivation of secondary school students. This result suggests that the higher the effective participation of secondary school students in the lessons, the more positive their internal motivations will be. It has also been determined that the more positive the internal motivations of secondary school students are, the less disaffected they will be in the courses. In turn, the more they engage in the courses, the less 
they will be disaffected. These results can be interpreted as, if the lessons are designed by considering the internal motivation resources of the students and the teachers carry out the lessons by taking this into account, the students will participate more effectively in the lessons and will be less disaffected.

Cothran and Ennis (2000) refer to teachers as bridge builders, influencing the effective participation of students. Researchers indicate that teachers' beliefs and their willingness to communicate to students have positive effects on the students' effective participation levels. In this context, it can be said that teachers have great influence on both the students' effective participation and their motivation.

On the basis of the findings of this study, it is suggested to plan the teaching process by considering the factors that will increase the secondary school students' effective participation and their motivations. In particular, teachers should pay attention on students' positive attitude development towards the courses, support the learner's autonomy, add intriguing activities to the lectures, be more tolerant towards failures, make use of student-centered strategies, methods and techniques.

\section{References}

Adıyaman, Y.Z. (2008). İlköğretim okullarında ögretmenin kullandiğg yöntem, teknik ve etkinliklerin ögrencinin derse katılımına etkisi. (Unpublished master's thesis). Yeditepe University, İstanbul.

Akpınar, B. , Batd1, V., \& Dönder, A. (2013). Evaluating primary school students' motivation levels in science education in terms of gender and class variables. Cumhuriyet International Journal of Education, 2(1), 15-26.

Archer L., Halsall, A., \& Hollingworth, S. (2007). Class, gender, (hetero) sexuality and schooling: Paradoxes within working - class girls' engagement with education and post - 16 aspirations. British Journal of Sociology of Education, 28(2), 165-180. https://doi.org/10.1080/01425690701192570

Areepattamannil, S., Freeman, J.G., \& Klinger, D.A. (2011). Intrinsic motivation, extrinsic motivation, and academic achievement among Indian adolescents in Canada and India. Social Psychology of Education, 14(3), 427-439. https://doi.org/10.1007/s11218-011-9155-1

Aykaç, N. (2014). Öğretim ilke ve yöntemleri. Ankara: Pegem Akademi Yayıncılık.

Aypay, A., \& Eryllmaz, A. (2011). Investigation of the relationship between high school students' motivation to class engagement and school burnout. Mehmet Akif Ersoy University Journal of Education Faculty, 11(21), 26-44.

Bozyiğit, N, Onan, T.S., Özçınar, A., \& Erdem, A. (2014). An in-class project model: Active learning and effective participation. Journal of Education and Future, 6, 15-24.

Bush, E.S., Ladd, G.W. \& Herald, S.L. (2006). Peer exclusion and victimization: processes that mediate the relation between peer group rejection and children's classroom engagement and achievement? Journal of Educational Psychology, 98(1), 1-13. https://doi.org/10.1037/0022-0663.98.1.1

Can, Ş. (2005). The role of clues and reinforcements in teaching-learning process. Journal of Social Sciences and Humanities Researchers, 14, 97-109.

Carini, R.M., Kuh, G.D., \& Klein, S.P. (2006). Student engagement and student learning: Testing the linkages. Research in Higher Education, 47(1), 1-32. https://doi.org/10.1007/s11162-005-8150-9

Carreira, J.M. (2011). Relationship between motivation for learning EFL and intrinsic motivation for learning in general among japanese elementary school students. System, 39, 90-102. https://doi.org/10.1016/j.system.2011.01.009

Ceylan, E., Sağırekmekçi, H., Tatar, E., \& Bilgin, İ. (2016). Investigation of middle school students' science course achievement according to their curiosity, attitude, and motivation levels. Uşak University Journal of Social Sciences, 9(1), 39-52.

Christenson, S.L., Reschly, A.L., \& Wylie, C. (2012). Handbook of Research on Student Engagement. New York: Springer. https://doi.org/10.1007/978-1-4614-2018-7

Cleary, T., \& Chen, P.P. (2009). Self-regulation, motivation, and math achievement in middle school: Variations across grade level and math context. Journal of School Psychology, 47, 291-314. https://doi.org/10.1016/j.jsp.2009.04.002

Coates, H. (2005). The Value of student engagement for higher education quality assurance. Quality in Higher 
Education, 11(1), 25-36. https://doi.org/10.1080/13538320500074915

Coates, H. (2007). A model of online and general campus-based student engagement. Assessment and Evaluation in Higher Education, 32(2), 121-141. https://doi.org/10.1080/02602930600801878

Cohen, J. (1988). Statistical power analysis for the behavioral sciences. Hillsdale, NJ: Lawrance Erlbaum Associates, Inc.

Corpus, J.H., McClintic-Gilbert, M.S., \& Hayenga, A.O. (2006). Understanding intrinsic and extrinsic motivation: Age differences and links to children's beliefs and goals. Poster presented at the annual meeting of the American Educational Research Association, San Francisco, CA.

Cothran, D.J., \& Ennis, C. D. (2000). Building bridges to student engagement: Communicating respect and care for students in urban high schools. Journal of Research and Development in Education, 33(2), 106-117

Çolak, E., \& Cirık, İ. (2015). Analysis of motivational orientation of secondary school students. Elementary Education Online, 14(4), 1307-1326.

Creswell, J.W. (2013). Research design: qualitative, quantitative, and mixed methods approaches. (4th Edt.). London: SAGE Publications.

Çöğür, H.Ç. (2010). THE usage of motivation tools in project management and its implementation in the Turkish construction sector. (Unpublished master's thesis). Çukurova Unversity, Adana.

Dallimore, E.J., Hertenstein, J.H., \& Platt, M.B. (2004). Classroom participation and discussion effectiveness: $\begin{array}{lllll}\text { student-generated } & \text { strategies. } & \text { Communication } & \text { Education, } & \text { 53, }\end{array}$ https://doi.org/10.1080/0363452032000135805

Deci, E.L., Vallerand, R.J., Pelletier, L.G., \& Ryan, R.M. (1991). Motivation in education: The self-determination perspective. The Educational Psychologist, 26(3), 326-346. https://doi.org/10.1207/s15326985ep2603\&4_6

Demir, M. K., \& Budak, H.(2016). The relationship between self-regulating, motivation and metacognitive skills and mathematics success of $4^{\text {th }}$ grade students. Buca Faculty of Education Journal, 41, 30-41.

Demirel, Ö. (2009). Öğretim ilke ve yöntemleri: Öğrenme sanatı (14. baskı). Ankara: Pegem Akademi Yayıncılık.

Eryllmaz, A. (2013). Motivation and amotivation at school: Developing the scale of expectations from teacher about class engagement. Mehmet Akif Ersoy University Journal of Education Faculty, 13(25), 1-18.

Eryllmaz, A., Yıldız, İ., \& Akın, S. (2011). Investigating of relationships between attitudes towards physics laboratories, motivation and amotivation for the class engagement. Eurasian Journal. Physics Chemistry Education (Special Issue), 59-64.

Fassinger, P.A. (2000). How classes influence students' participation in college classrooms. Journal of Classroom Interaction, 35, 38-47.

Furrer, C. \& Skinner, E. (2003). Sense of relatedness as a factor in children's academic engagement and performance. Journal of Educational Psychology, 95, 148-162. https://doi.org/10.1037/0022-0663.95.1.148

Graham, S., \& Weiner, B. (1996). Theories and Principles of Motivation, in: Berliner, David C. [Ed]; Calfee, Robert C. [Ed], [1996]. Handbook of educational psychology. , [pp. 63-84]. New York, NY, US: Macmillan Library Reference Usa; London, England: Prentice Hall International.

Gunuc, S. (2014). The relationships between student engagement and their academic achievement. International Journal on New Trends in Education and Their Implications, 5(4), 216-231.

Guthrie, J.T., Wigfield, A., Metsala, J.L., \& Cox, K.E. (1999). Motivational and cognitive predictors of text comprehension and reading amount. Scientific Studies of Reading, 3, 231-256. https://doi.org/10.1207/s1532799xssr0303_3

Guthrie, J.T., \& Wigfield, A. (1997). Reading engagement: A rational for theory and teaching. In J. T. Guthrie \& A. Wigfield (Eds.). Reading engagement: Motivating readers through integrated instruction (pp. 1-22). Newark, DE: International Reading Association.

Güneri, E. (2013). The secondary school students' self efficacy perceptions and engagement \& disaffection in Science and Tecnology course. (Unpublished master's thesis). Çanakkale On Sekiz Mart University, Çanakkale.

Güvenç, H. (2011). Ortaöğretim öğrencilerinin coğrafya dersine katılım durumları ve güdüsel düzenlemeleri. 20. Ĕgitim Bilimleri Kurultayl, 8-10 Eylül 2011, Bildiri Özetleri, s.573. Burdur. 
Güvenç, H. (2015). Development and adaptation study of engagemet \&disaffection scale. Ahi Evran University Journal of Kirşehir Education Faculty (JKEF), 16(1), 255-267.

Güvenç, H., \& Koç, C. (2016). Middle school students' engagement \& disaffection and help-seeking tendencies. Trakya University Journal of Social Science, 18(2), 347-366.

Hannula, M. (2005). Affect in mathematical thinking and learning. The Future of Mathematics Education and Mathematics Learning. BIFEB Strobl, Austria.

Harter, S. (1981). A new self-report scale of intrinsic versus extrinsic orientation in the classroom: Motivational and

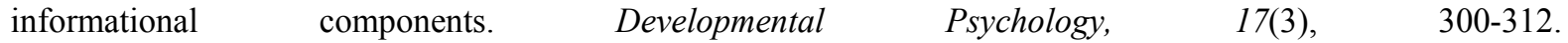
https://doi.org/10.1037/0012-1649.17.3.300

Harris, L.R. (2008). A phenomenographic investigation of teacher conceptions of student engagement in learning. The Australian Educational Researcher, 5(1), 57-79. https://doi.org/10.1007/BF03216875

İnel-Ekici, D., Kaya, K., \& Mutlu, O. (2014). Investigating of motivation about science learning of middle school students to different variables: The case of Usak province. Mersin University Journal of the Faculty of Education, 10(1), 13-26.

Karataş, H., \& Erden, M. (2012). Bilingual equivalence, validity and reliability of academic motivation scale. e-Journal of New World Sciences Academy, 7(4), 983-1003.

Kiefer, S.M., Alley, K.M., \& Ellerbrock, C.R. (2015). Teacher and peer support for young adolescents' motivation, engagement, and school belonging. Research in Middle Level Education (RMLE) Online, 38(8), 1-18. https://doi.org/10.1080/19404476.2015.11641184

Kinzie, J., Gonyea, R., Kuh, G. D., Umbach, P., Blaich, C., \& Korkmaz, A. (2007, December). The relationship between gender and student engagement in college. Paper presented at the 32nd Annual Conference of the Association for the Study of Higher Education. Louisville, KY. Retrieved December 25, 2017, from http://cpr.indiana.edu/uploads/Gender\%20and\%20Student\%20Engagement\%20in\%20College \%20ASHE\%2020 07\%20Kinzie\%20et\%20al.,.pdf

Kutu, H., \& Sözbilir, M. (2011). Adaptation of instructional materials motivation survey to Turkish: A validity and reliability study. Necatibey Faculty of Education Electronic Journal of Science and Mathematics Education, $5(1), 292-312$.

Lai, P.Y., Chan, K.W., \& Wong, K.Y.A. (2006). A study of intrinsic motivation, achievement goals and study strategies of Hong Kong Chinese secondary students. [Online] Retrieved on 22-October2017, at http://www.aare.edu.au/data/publications/2006/lai06321.pdf

Lee, C.S., Hayes, K.N., Seitz, J., Distefano, R., \& O'Connor, D. (2016). Understanding motivational structures that differentially predict engagement and achievement in middle school science. International Journal of Science Education, 38(2), 192-215. https://doi.org/10.1080/09500693.2015.1136452

Lee, W., \& Reeve, J. (2012). Teachers' estimates of their students' motivation and engagement: being in synch with students. Educational Psychology, 32(6), 727-747. https://doi.org/10.1080/01443410.2012.732385

Lewis, A.D. (2010). Facilitating student engagement: The importance of life satisfaction. (Unpublished doctorate thesis). South Carolina University, USA.

Lepper, M.R., Corpus, J.H., \& Iyengar, S.S. (2005). Intrinsic and extrinsic motivational orientations in the classroom: Age differences and academic correlates. Journal of Educational Psychology, 97(2), 184-196. https://doi.org/10.1037/0022-0663.97.2.184

Lucas, I.R., Pulido, D., Miraflores, E., Ignacio, A., Tacay, M., \& Lao, J. (2010). A study on the intrinsic motivation factors in second language learning among selected freshman students. Philippine ESL Journal, 4, 3-23.

Matteson, S.M., Swarthout, M.B., \& Zientek, L.R. (2011). Student motivation: perspectives from mathematics teachers. Action in Teacher Education, 33(3), 283-297. https://doi.org/10.1080/01626620.2011.592123

Midgley, C., Feldlaufer, H., \& Eccles, J.S. (1989). Student/teacher relations and attitudes toward mathematics before and after the transition to junior high school. Chil d development, 981-992. https://doi.org/10.2307/1131038

Ormrod, J.E. (2015). Öğrenme psikolojisi. (Çev. M. Baloğlu). Ankara: Nobel Yayıncılık.

Othman, N., \& Leng, K.B. (2011). The relationship between self-concept, intrinsic motivation, selfdetermination and academic achievement among Chinese primary school students. International Journal of Psychological Studies, 
3(1), 90-98. https://doi.org/10.5539/ijps.v3n1p90

Pajares, F. (1996). Assessing self efficacy beliefs and academic success: the case for specificity and correspondence. Annual Meeting of the American Educational Research Association, New York.

Park, S-Y. (2005). Student engagement and classroom variables in improving mathematics achievement. Asia Pacific Education Review, 6(1), 87-97. https://doi.org/10.1007/BF03024970

Pintrich, P.R., Marx, R.W., \& Boyle, R.A. (1993). Beyond cold conceptual change: the role of motivational beliefs and classroom contextual factors in the process of conceptual change. Review of Educational Research, 63, 167-199. https://doi.org/10.3102/00346543063002167

Rusillo, M.T.C., \& Airas, P.F.C. (2004). Gender differences in academic motivation of secondary school children. Electronic Journal of Research in Educational Psychology and Psychopedagogy, 2(1), 97-112.

Ryan, A.M., \& Patrick, H. (2001). The classroom social environment and changes in adolescents' motivation and engagement during middle school. American Educational Research Journal, 38(2), 437-460. https://doi.org/10.3102/00028312038002437

Saritepeci, M. (2012). The effect of blended learning environment on students' engagement, academic achivement, attitude and motivation to the course of social studies in seventh grade in primary education. (Unpublished master's thesis). Gazi University, Ankara.

Sarıtepeci, M., \& Çakır, H. (2015). The effect of blended learning environments on student's academic achievement and student engagement: A study on social studies course. Education and Science, 40(177), 203-216.

Schick, A., \& Schwedes, H. (1999). The influence of interest and self-concept on students' actions in physics lessons. Annual meeting of the national 159 association for research in science teaching. Retrieved from http://files.eric.ed.gov/fulltext/ED444836.pdf.

Schunk, D.H. (1995). Self efficacy and education and instruction. In Maddux (ed.), Self efficacy, adaptation and adjustment: theory, research and application. New York: Plenum Press. Pp. 281-303. https://doi.org/10.1007/978-1-4419-6868-5_10

Schunk, D.H. (2009). Learning theories: An educational perspective. Ankara: Nobel.

Sever, M., Ulubey, Ö., Toraman, Ç., \& Türe, E. (2014). An analysis of high school students' classroom engagement in relation to various variables. Education and Science, 39(176), 183-198. https://doi.org/10.15390/EB.2014.3633

Skinner, E.A., Kindermann, T.A., \& Furrer, C.J. (2009). A motivational perspective on engagement and disaffection: conceptualization and assesment of children's behavioral and emotion participation in academic activities in the classroom. Educational and Psychological Measurement, 69, 493-525. https://doi.org/10.1177/0013164408323233

Tariq, S., Hussain, S., \& Mahmood, S. (2011). The relationship between intrinsic motivation and academic achievement of male and female students at university level in Pakistan: A case study. Journal of Education and Vocational Research, 2(5), 154-161.

Tolunay-Ateş, Ö. (2016). Examination of the relationship between the social support and the motivational orientation perceived by secondary school students using structural equation model. Kalem International Journal of Education and Human Sciences, 6(2), 357-386.

Trowler, V. (2010). Student engagement literature review. The Higher Education Academy. Retrieved from https://www.heacademy.ac.uk/system/files/studentengagementliteraturereview_1.pdf

Türk Dil Kurumu (TDK) (2011). Büyük Türkçe sözlük. Ankara: Türk Dil Kurumu Yayınları.

Uluçay, B., \& Güven, S. (2017). The relationship between mathematical motivation and perceived teacher closeness of secondary school students. Journal of Research in Education and Teaching, 6(3), 252-266.

Uzun, N., \& Keleş, Ö. (2010). Evaluation of the motivation for science learning according to some demographic characteristics. Gazi University Journal of Gazi Educational Faculty, 30(2), 1-16.

Wang, Z., Bergin, C., \& Bergin, D.A. (2014). Measuring engagement in fourth to twelfth grade classrooms: The classroom engagement inventory. School Psychology Quarterly, 29(4), 517-535. https://doi.org/10.1037/spq0000050 
Wang, M., \& Eccles, J.S. (2012). Adolescent Behavioral, Emotional, and Cognitive Engagement Trajectories in School and Their Differential Relations to Educational Success. Journal of Research on Adolescence, 22(1), 31-39. https://doi.org/10.1111/j.1532-7795.2011.00753.x

Wang, M.T., \& Holcombe, R. (2010). Adolescents' perceptions of school environment, engagement, and academic achievement in middle school.American Educational Research Journal, 47(3), 633-662. https://doi.org/10.3102/0002831209361209

Wentzel, K.R., Battle, A., Russell, S.L., \& Looney, L.B. (2010). Social supports from teachers and peers as predictors of academic and social motivation. Contemporary Educational Psychology, 35, 193-202. https://doi.org/10.1016/j.cedpsych.2010.03.002

Woolfolk Hoy, A. (2015). Ĕgitim psikolojisi (Çev. Özen, D.). Kaknüs Yayınları

Viau, R. (2015). La motivation a apprendre en millieu scolaire. (Y. Budak, Trans.), Ankara: An1.

Yaman, S., \& Dede, Y. (2007). Examination of motivation level of students towards science and mathematics by some variables. Educational Administration: Theory and Practice, 52, 615-638.

Yenice, N., Saydam, G., \& Telli, S. (2012). Determining factors effecting on primary school students' motivation towards science learning. Ahi Evran University Journal of Kirşehir Education Faculty (JKEF), 13(2), 231-247.

Yerlikaya, İ. (2014). The study of motivation of primary and secondary school students into education in terms of various varieties. Journal of History School (JOHS), 7(19),773-795. https://doi.org/10.14225/Joh602 